\title{
Pengaruh kecerdasan emosional dan kecerdasan sosial terhadap kinerja karyawan promotor produk pada PT. Blue Ocean Heart Kota Malang
}

\author{
Eko Wahyudi, Elfia Nora* \\ Universitas Negeri Malang, Jl. Semarang No. 5 Malang, Jawa Timur, Indonesia \\ *Penulis korespondensi, Surel: elfia.nora.fe@um.ac.id
}

Paper received: 3-5-2021; revised: 24-5-2021; accepted: 28-5-2021

\begin{abstract}
This study aims (1) to determine how the description of emotional intelligence, social intelligence, and employee performance, (2) to determine the effect of emotional intelligence on employee performance, (3) to determine the effect of social intelligence on employee performance. This research was conducted on 51 employees at a company engaged in the distribution or sales of Vivo smartphones in Malang, namely PT. Blue Ocean Heart, Malang city. The sampling technique in this study was the sample random sampling technique, and the data analysis technique used in this study was descriptive statistical techniques and multiple linear regression. The results of this study indicate: (1) the level of emotional intelligence, social intelligence, and employee performance is in the good or smart category, (2) emotional intelligence has a positive and significant effect on employee performance, (3) social intelligence has a positive and significant effect on employee performance.
\end{abstract}

Keywords: Emotional Intelligence; Social Intelligence; Employee Performance

\begin{abstract}
Abstrak
Penelitian ini bertujuan (1) untuk mengetahui bagaimana deskripsi kecerdasan emosional, kecerdasan sosial, dan kinerja karyawan, (2) untuk mengetahui pengaruh kecerdasan emosional terhadap kinerja karyawan, (3) untuk mengetahui pengaruh kecerdasan sosial terhadap kinerja karyawan. Penelitian ini dilakukan terhadap 51 orang karyawan pada perusahaan yang bergerak dalam bidang distribusi atau penjualan smartphone Vivo di kota Malang yaitu PT. Blue Ocean Heart kota Malang. Teknik pengambilan sampel dalam penelitian ini adalah teknik sample random sampling dan analisis teknik analisis data dalam penelitian ini menggunakan teknik statistik deskriptif dan regresi linier berganda. Hasil penelitian ini menunjukkan: (1) tingkat kecerdasan emosional, kecerdasan sosial, dan kinerja karyawan masuk dalam kategori baik atau cerdas, (2) kecerdasan emosional berpengaruh positif dan signifikan terhadap kinerja karyawan, (3) kecerdasan sosial berpengaruh positif dan signifikan terhadap kinerja karyawan.
\end{abstract}

Kata kunci: Kecerdasan Emosional; Kecerdasan Sosial; Kinerja Karyawan

\section{Pendahuluan}

Setiap perusahaan menginginkan karyawannya memberikan kinerja yang optimal, karena keberhasilan dan kegagalan suatu perusahaan lebih ditentukan oleh ada atau tidak adanya sumber manusia yang andal yang menggerakkan dan mengelola perusahaan (Collins, 2015). kinerja perusahaan tercermin dari kinerja karyawannya. dalam pencapaian kinerja yang tinggi, perlu dilandaskan pada beberapa pendekatan diantaranya adalah pendekatan psikologis dan organisasi (Mangkunegara, 2010). Pendekatan psikologis banyak macamnya menurut Goleman dalam (Sumiyarsih et al., 2012) 80\% kesuksesan hidup seseorang, termasuk keberhasilan di lingkungan bisnis atau kerja, dipengaruhi oleh kecerdasan emosionalnya,

This work is licensed under a Creative Commons Attribution-ShareAlike 4.0 International License. 
kecerdasan emosional dapat membantu seorang karyawan dalam melaksanakan atau menjalankan pekerjaanya.

Kecerdasan emosional merupakan faktor penting untuk menentukan kesuksesan dalam hidup dan kesejahteraan psikologis (Jorfi et al., 2010). Setiap pekerjaan membutuhkan tipe kecerdasan emosional yang berbeda seperti responden dalam penelitian ini adalah seorang promotor produk. promotor produk memiliki peran sebagai pelaksana kegiatan jual beli produk kepada konsumen. dimana kesuksesan dalam penjualan membutuhkan kemampuan empati untuk mengidentifikasi suasana hati pelanggan dan keterampilan interpersonal untuk memutuskan kapan akan menawarkan produk dan kapan harus diam (Jorfi et al., 2010). seperangkat kecakapan khusus seperti empati, disiplin diri, dan inisiatif mampu membedakan orang-orang sukses dengan mereka yang hanya cukup baik untuk mempertahankan pekerjaan mereka (Mc.Clelland dalam (Rahmasari, 2012).

(Utami, 2006) menjelaskan bahwa kecerdasan emosional dapat dipandang secara luas sebagai suatu keunggulan atau keistimewaan dan dapat diidentifikasi sebagai suatu penyampaian layanan relatif istimewa terhadap pelanggan. Tenaga penjual yang memiliki kecerdasan emosional yang tinggi akan lebih menarik simpati pembeli dan kecenderungan pembeli selalu mau membeli produk yang ditawarkan akan tetapi tenaga penjual yang kecerdasan emosionalnya rendah dapat dilihat dari penjual yang kurang tenang, tidak mampu menimbulkan simpati dan pembeli cenderung tidak jadi membeli (Utomo \& Suharyono, 2017). keberhasilan seorang karyawan tidak cuma didukung oleh kemampuan intelektual saja. Tetapi juga didukung oleh kemampuan individu dalam penyesuaian emosi dalam berhubungan dengan seseorang. (Daniel Goleman, 2017), Menyatakan seseorang dapat mengontrol emosinya dengan baik maka akan dapat menghasilkan kinerja yang baik pula. Faktor yang sama pentingnya dengan kombinasi kemampuan teknis dan analisis untuk menghasilkan kinerja yang optimal. Goleman dalam (Rahmasari, 2012) kemampuan kecerdasan emosional adalah pendorong kinerja puncak. Kemampuan-kemampuan kognitif seperti Big picture thinking dan Long term vision juga penting, tetapi ketika dibandingkan antara kemampuan teknikal, IQ dan kecerdasan emosional sebagai penentu kinerja yang cemerlang tersebut, maka kecerdasan emosional menduduki porsi lebih penting dua kali dibandingkan dengan yang lain pada seluruh tingkatan jabatan. Setiap karyawan diharapkan dapat mengendalikan emosi secara sehat di dalam lingkungan kerja baik terhadap sesama karyawan atau rekan kerja, atasan, dan calon konsumen. Sehingga terwujud kerjasama dan hubungan yang baik antar tim atau antar bagian untuk menunjang keefektifan penyelesaian pekerjaan dan tanggung jawab yang diberikan oleh perusahaan.

Selain kecerdasan emosional seorang promotor produk juga harus memiliki dan menerapkan kecerdasan sosial, kecerdasan sosial merupakan kecerdasan yang mencakup interaksi, kemampuan untuk memahami dan mengelola hubungan sehingga mampu mempengaruhi orang lain dan erat kaitanya dengan keahlian menawarkan barang. Menurut Buzan dalam (Ambarita, 2014), kecerdasan sosial adalah suatu kemampuan diri seseorang dalam bergaul di lingkungan masyarakat dan kemampuan berinteraksi sosial dengan orangorang-orang di sekeliling atau sekitarnya.

Menurut (Lathesh \& Avadhani, 2018), kecerdasan sosial juga disebut kecerdasan bisnis, dalam mengatasi hambatan, kecerdasan sosial berperan secara dramatis dalam meningkatkan kinerja, memaksimalkan kesuksesan pribadi dan organisasi. Dalam hal ini seorang promotor 
produk harus cerdas secara sosial agar mampu berinteraksi dan mengelola hubungan dengan calon pembeli sehingga calon pembeli tertarik dan mau membeli produk yang ditawarkan. Menurut (Mudzakir et al., 2018), penjual dan pembeli akan berinteraksi sebagaimana proses sosialisasi pada masyarakat umumnya. kemampuan berinteraksi sosial adalah salah satu kemampuan yang harus dimiliki oleh tenaga penjual di sebuah perusahaan karena seorang promotor produk harus memperoleh kepercayaan dari konsumen, kepercayaan didapat melalui proses interaksi sosial dengan memahami orang lain. Menurut Thorndike dalam (Mudzakir et al., 2018), kemampuan memahami dan mengelola orang lain tersebut merupakan kemampuan kecerdasan sosial. (Mamangkey et al., 2018) mengungkapkan jika karyawan memiliki kompetensi /kemampuan seperangkat kecerdasan salah satunya kecerdasan sosial, dalam bekerja maka kecerdasan ini akan membantu karyawan dalam melakukan pekerjaan dengan hasil yang baik. Semakin baik dan tinggi tingkat kecerdasan sosial karyawan maka akan semakin baik kemampuan interaksi karyawan untuk bekerja melayani konsumen.

PT. Blue Ocean Heart kota Malang merupakan perusahaan yang bergerak pada bidang telekomunikasi dan smartphone yang menaungi Vivo. Brand ini sedang marak dan berkembang. Kegiatan perusahaan meliputi service center dan distribusi dan penjualan smartphone Vivo ke semua toko handphone di kota Malang. Penjualan smartphone Vivo bergantung dengan karyawan promotor produk. Jika terjadi penurunan kinerja promotor produk akan berimbas fatal bagi kinerja perusahaan. Kurangnya kemampuan mengendalikan emosi dan kurangnya kemampuan interaksi sehingga promotor tidak bisa meyakinkan dan mempengaruhi pembeli dengan produk yang dijualnya (Trainer Perusahaan, 2020). umumnya tidak semua karyawan memiliki dasar pengendalian dan penerapan kecerdasan emosional dan kecerdasan sosial yang baik sehingga pengukuran dari dua kecerdasan ini perlu dilakukan dengan tujuan untuk mengetahui tingkat kemampuan karyawan dalam pengendalian dan penerapan kecerdasan emosional dan kecerdasan sosial untuk upaya menghindari penurunan kinerja. Berdasarkan uraian latar belakang yang telah dijelaskan diatas maka peneliti tertarik untuk menguji Pengaruh Kecerdasan Emosional dan Kecerdasan Sosial Terhadap Kinerja Karyawan Promotor Produk Pada PT. Blue Ocean Hearth Kota Malang. Berdasarkan latar belakang penelitian, maka tujuan penelitian dalam penelitian ini adalah sebagai berikut:

(1) Untuk mengetahui bagaimana deskripsi kecerdasan emosional, kecerdasan sosial, dan kinerja karyawan bagian promotor produk di PT. Blue Ocean Heart kota Malang.

(2) Untuk mengetahui pengaruh kecerdasan emosional terhadap kinerja karyawan bagian promotor produk di PT. Blue Ocean Heart kota Malang.

(3) Untuk mengetahui pengaruh kecerdasan sosial terhadap kinerja karyawan promotor produk di PT. Blue Ocean Heart kota Malang.

\section{Metode}

\subsection{Sampel dan Prosedur}

Responden penelitian adalah karyawan bagian promotor produk di PT. Blue Ocean Hearth kota Malang, dengan populasi sebanyak 58 orang dan setelah dihitung menggunakan rumus Slovin sampel penelitian ini menjadi 51 orang. Teknik sample yang digunakan ialah Teknik simple random sampling yang dimana pengambilan anggota populasi yang dilakukan secara acak tanpa memperhatikan strata yang ada dalam populasi itu (Sugiyono, 2016) 
pengambilan data melalui kuesioner dilakukan langsung oleh peneliti dengan mengunjungi toko penempatan promotor di kota Malang.

Kuesioner yang digunakan dalam penelitian ini adalah kuesioner dalam berbentuk tertutup, dimana kuesioner jenis ini sudah disediakan alternative jawaban sehingga responden cukup memilih jawaban yang telah disediakan. Pernyataan kuesioner diberikan dalam bahasa Indonesia. Analisis data pada penelitian ini menggunakan program SPSS versi 26.

Gambar rancangan penelitian dalam penelitian ini dapat dilihat pada Gambar 1 dibawah ini.

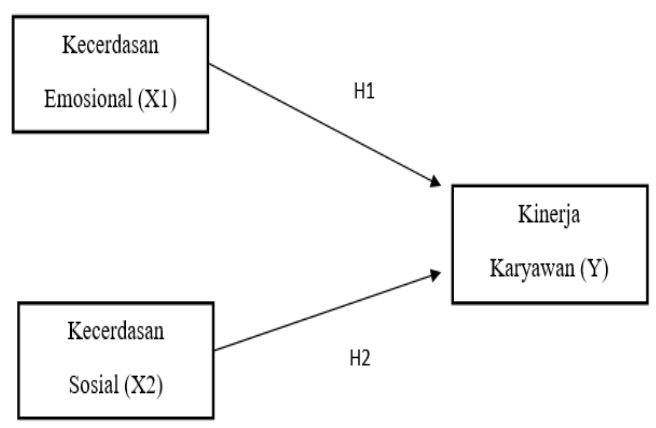

Gambar 1. Rancangan Penelitian

Semua item dan indikator pada penelitian ini merupakan adaptasi dari berbagai penelitian sebelumnya. Untuk mengukur kecerdasan emosional menggunakan dimensi pengukuran dari (Law \& Song, 2004) yang membagi kecerdasan emosional dalam empat dimensi pengukuran, yaitu: Self Emotion Appraisal (SEA), Others Emotion Appraisal (OEA), Use of Emotion (UOE), dan Regulation of Emotion (ROE). Pengukuran kecerdasan sosial menggunakan adaptasi dimensi pengukuran dari (Silvera et al., 2001) yang membagi tiga dimensi utama dari pengukuran kecerdasan sosial, yaitu: Social Information Processing, Social Skills, dan Social Awareness. Dan variabel kinerja karyawan diukur dengan pengukuran dari (Mathis \& John, 2006) dengan berfokus kepada indikator yang diungkapkan oleh Trainer perusahaan yaitu Kualitas, Kuantitas, dan kehadiran.

Penelitian ini menggunakan skala likert dengan lima kriteria jawaban dari sangat setuju sampai sangat tidak setuju, hal untuk mengukur sikap, pendapat dan persepsi seseorang atau kelompok orang tentang fenomena sosial (Sugiyono, 2016).

\subsection{Analisis Data}

Demografi responden pada penelitian ini sebanyak 51 orang, karakteristik berdasarkan jenis kelamin sebanyak 27 responden atau 52,94\% laki-laki dan 24 responden atau 47,05\% perempuan. Berdasarkan usia ada 30 responden atau 58,82\% yang memiliki umur dengan rentang 18-25 tahun, 18 responden atau 35,29\% yang memiliki rentang umur 26-30 tahun, dan juga 3 responden atau 5,88\% yang memiliki rentang umur 31-35 tahun. Berdasarkan pendidikan sebanyak 47 responden atau 92,15\% memiliki pendidikan SMA/Sederajat, 2 responden atau 3,92\% memiliki pendidikan D3/Diploma, dan 2 orang atau 3,92\% memiliki pendidikan S1/Sarjana. Untuk kriteria masa kerja sebanyak 39 responden atau $76,47 \%$ memiliki masa kerja $<2$ tahun, dan 12 responden atau $23,52 \%$ memiliki masa kerja $\geq 2$ Tahun. 
Tabel 1 menyajikan statistik deskriptif, nilai $r$ hitung, dan koefisien alpha. Pada tabel 1 menunjukkan bahwa semua variabel memiliki grand mean berkisar antara 3,51 - 3,61 hasil ini dapat diklasifikasikan ke dalam kategori Tinggi/baik.

Tabel 1. Analisis Deskriptif, r Hitung, Koefisien Alpha

\begin{tabular}{|c|c|c|c|c|}
\hline & Variabel & Mean & $\begin{array}{l}\text { corrected } \\
\text { item-total }\end{array}$ & Cronbach's \\
\hline & Kecerdasan Emosional & 3,57 & & 0,797 \\
\hline $\mathrm{X} 1.1$ & $\begin{array}{l}\text { Saya punya alasan kuat mengapa saya } \\
\text { memiliki perasaan-perasaan tertentu } \\
\text { hampir sepanjang waktu }\end{array}$ & 3,24 & 0,404 & \\
\hline $\mathrm{X} 1.2$ & $\begin{array}{l}\text { Saya sangat paham perasaan-perasaan saya } \\
\text { sendiri }\end{array}$ & 3,80 & 0,562 & \\
\hline $\mathrm{X} 1.3$ & $\begin{array}{l}\text { Saya sungguh memahami apa yang saya } \\
\text { rasakan }\end{array}$ & 3,84 & 0,420 & \\
\hline $\mathrm{X} 1.4$ & $\begin{array}{l}\text { Saya selalu dapat mengetahui emosi } \\
\text { pembeli dari perilakunya }\end{array}$ & 3,53 & 0,505 & \\
\hline $\mathrm{X} 1.5$ & $\begin{array}{l}\text { Saya mampu mengamati dengan baik } \\
\text { perasaan yang dirasakan pembeli }\end{array}$ & 3,57 & 0,493 & \\
\hline X1.6 & $\begin{array}{l}\text { Saya peka dengan perasaan dan emosi } \\
\text { pembeli }\end{array}$ & 3,53 & 0,448 & \\
\hline $\mathrm{X} 1.7$ & $\begin{array}{l}\text { Saya sangat paham dengan perasaan- } \\
\text { perasaan orang-orang disekitar saya }\end{array}$ & 3,12 & 0,564 & \\
\hline $\mathrm{X} 1.8$ & $\begin{array}{l}\text { Saya selalu menetapkan tujuan untuk diri } \\
\text { sendiri dan kemudian mencoba yang } \\
\text { terbaik untuk mencapai tujuan itu }\end{array}$ & 3,96 & 0,419 & \\
\hline $\mathrm{X} 1.9$ & $\begin{array}{l}\text { Saya selalu mengatakan pada diri sendiri } \\
\text { bahwa saya orang yang memiliki } \\
\text { kemampuan/berkompetensi }\end{array}$ & 3,88 & 0,755 & \\
\hline $\mathrm{X} 1.10$ & $\begin{array}{l}\text { Saya orang yang mampu memotivasi diri } \\
\text { sendiri }\end{array}$ & 3,69 & 0,562 & \\
\hline $\mathrm{X} 1.11$ & $\begin{array}{l}\text { Saya akan selalu mendorong diri untuk } \\
\text { melakukan yang terbaik }\end{array}$ & 4,00 & 0,597 & \\
\hline $\mathrm{X} 1.12$ & $\begin{array}{l}\text { Saya sangat mampu mengendalikan } \\
\text { perasaan-perasaan saya sendiri }\end{array}$ & 3,63 & 0,734 & \\
\hline $\mathrm{X} 1.13$ & $\begin{array}{l}\text { Saya selalu dapat segera meredam emosi } \\
\text { saya ketika sedang marah }\end{array}$ & 3,18 & 0,530 & \\
\hline $\mathrm{X} 1.14$ & $\begin{array}{l}\text { Saya punya kendali yang bagus atas } \\
\text { perasaan-perasaan saya sendiri }\end{array}$ & 3,14 & 0,413 & \\
\hline & Kecerdasan Sosial & $3, \mathbf{5 1}$ & & 0,921 \\
\hline $\mathrm{X} 2.1$ & Saya mudah bergaul di lingkungan kerja & 4,04 & 0,691 & \\
\hline $\begin{array}{l}\mathrm{X} 2.2 \\
\mathrm{X} 23\end{array}$ & Saya mudah masuk ke dalam situasi baru & 3,67 & 0,653 & \\
\hline $\mathrm{X} 2.4$ & $\begin{array}{l}\text { Saya merasa nyaman berada disekitar } \\
\text { pembeli yang tidak saya kenal }\end{array}$ & 3,53 & 0,747 & \\
\hline $\mathrm{X} 2.5$ & Saya mudah mengenal pembeli dengan baik & 3,51 & 0,738 & \\
\hline $\mathrm{X} 2.6$ & $\begin{array}{l}\text { Saya mudah menemukan topik percakapan } \\
\text { yang baik dengan pembeli }\end{array}$ & 3,59 & 0,698 & \\
\hline $\mathrm{X} 2.7$ & Saya dapat memprediksi perilaku pembeli & 3,43 & 0,816 & \\
\hline $\mathrm{X} 2.8$ & $\begin{array}{l}\text { Saya tahu bagaimana Tindakan saya akan } \\
\text { mempengaruhi perasaan pembeli }\end{array}$ & 3,61 & 0,787 & \\
\hline $\mathrm{X} 2.9$ & $\begin{array}{l}\text { Saya dapat memprediksi bagaimana } \\
\text { pembeli akan bereaksi terhadap perilaku } \\
\text { saya }\end{array}$ & 3,39 & 0,637 & \\
\hline
\end{tabular}




\begin{tabular}{|c|c|c|c|c|}
\hline $\mathrm{X} 2.10$ & $\begin{array}{l}\text { Saya dapat mengerti maksud pembeli } \\
\text { melalui ekspresi, dan Bahasa tubuh }\end{array}$ & 3,47 & 0,507 & \\
\hline $\mathrm{X} 2.11$ & Saya memahami keinginan pembeli & 3,65 & 0,849 & \\
\hline $\mathrm{X} 2.12$ & $\begin{array}{l}\text { Saya mudah memahami pilihan yang akan } \\
\text { dibuat pembeli }\end{array}$ & 3,51 & 0,758 & \\
\hline $\mathrm{X} 2.13$ & $\begin{array}{l}\text { Saya merasa biasa saja dengan hal-hal yang } \\
\text { pembeli lakukan }\end{array}$ & 3,00 & 0,510 & \\
\hline $\mathrm{X} 2.14$ & $\begin{array}{l}\text { Saya akan meminimalisir sebab-sebab } \\
\text { pembeli marah kepada saya }\end{array}$ & 3,63 & 0,543 & \\
\hline $\mathrm{X} 2.15$ & $\begin{array}{l}\text { Ketika saya mengatakan apa yang saya } \\
\text { pikirkan, pembeli tidak marah kepada saya }\end{array}$ & 3,31 & 0,600 & \\
\hline $\mathrm{X} 2.16$ & Bagi saya, pembeli mudah diprediksi & 3,00 & 0,612 & \\
\hline & Kinerja Karyawan & 3,61 & & 0,852 \\
\hline Y1 & $\begin{array}{l}\text { Menurut saya teman saya ini selalu } \\
\text { menerapkan 3S (Senyum, Salam, Sapa), } \\
\text { dalam rangka menjaga kualitas pelayanan } \\
\text { terhadap konsumen }\end{array}$ & 4,24 & 0,653 & \\
\hline Y2 & $\begin{array}{l}\text { Menurut saya teman saya ini dapat } \\
\text { mencapai standart kualitas kerja yang telah } \\
\text { ditetapkan oleh perusahaan dengan baik }\end{array}$ & 3,67 & 0,861 & \\
\hline Y3 & $\begin{array}{l}\text { Menurut saya teman saya ini dapat } \\
\text { melaksanakan pekerjaan dengan baik, } \\
\text { dengan pengetahuan yang dia miliki }\end{array}$ & 3,65 & 0,733 & \\
\hline Y4 & $\begin{array}{l}\text { Menurut saya teman saya ini mampu } \\
\text { bekerja sesuai standar target perusahaan }\end{array}$ & 3,57 & 0,794 & \\
\hline Y5 & $\begin{array}{l}\text { Menurut saya teman saya ini dating kerja } \\
\text { lebih awal sehingga siap untuk bekerja } \\
\text { ketika jam kerja dimulai }\end{array}$ & 3,57 & 0,789 & \\
\hline Y6 & $\begin{array}{l}\text { Menurut saya teman saya ini pulang dari } \\
\text { tempat kerja sesuai dengan jam kerja yang } \\
\text { telah ditentukan }\end{array}$ & 3,08 & 0,669 & \\
\hline Y7 & $\begin{array}{l}\text { Menurut saya teman saya ini tidak pernah } \\
\text { keluar tanpa izin saat jam kantor }\end{array}$ & 3,53 & 0,491 & \\
\hline Y8 & $\begin{array}{l}\text { Menurut saya teman saya ini menghindari } \\
\text { tidak masuk kerja jika tidak mendesak }\end{array}$ & 4,65 & 0,689 & \\
\hline
\end{tabular}

Pada tabel 1 dapat dilihat jika nilai corrected item-total correlation $>\mathrm{r}$ tabel, $\mathrm{r}$ tabel sebesar $(0,361)$ maka item pada setiap variabel dinyatakan valid dan dapat menjadi alat ukur Pengujian validitas suatu kuesioner dikatakan valid apabila pernyataan pada kuesioner mampu mengungkap suatu yang diukur oleh kuesioner tersebut. Validitas digunakan untuk mengukur valid berdasarkan dari nilai corrected item-total correlation masing-masing item kuesioner (Ghozali, 2012).

Dalam penelitian ini juga menggunakan uji reliabilitas dengan membandingkan Cronbach's Alpha dengan standar koefisien alpha. Uji Reliabilitas dilakukan untuk melihat suatu kuesioner dikatakan dapat diandalkan apabila seseorang dihadapkan dengan pertanyaan yang konsisten dari waktu ke waktu. Instrument penelitian yang dapat dipercaya dan reliabel akan menghasilkan apa yang dapat dipercaya pula (Arikunto, 2010). Dasar pengambilan keputusannya jika nilai Cronbach's Alpha dari masing-masing variabel lebih besar > 0,600 maka dinyatakan reliabel atau dapat diandalkan Semakin mendekati 1 maka mengindikasikan semakin tinggi pula konsistensi internal reliabilitasnya. Dilihat dari nilai 
Cronbach's Alpha ketiga variabel penelitian ini sudah lebih besar dari $>600$ maka sudah dinyatakan reliabel.

Untuk mengetahui layak atau tidaknya model regresi yang dihasilkan atas variabelvariabel yang digunakan didalam penelitian. Untuk menghindari hasil bias dalam penelitian maka dilakukan uji asumsi klasik termasuk didalamnya adalah uji normalitas, uji multikolinearitas dan uji heteroskedasitas.

\subsubsection{Uji normalitas}

Uji ini bertujuan untuk menguji apakah dalam model regresi variabel bebas dan variabel terikat memiliki distribusi normal atau tidak. untuk uji normalitas peneliti menggunakan metode kolmogrov-smirnov metode ini memiliki ketentuan jika nilai signifikasi (Asymp. Sig. 2tailed) > 0,05 maka data berdistribusi normal, dan sebaliknya terlihat pada Tabel 2 .

Tabel 2. Uji Normalitas Metode Kolmogrov-Smirnov

\begin{tabular}{lll}
\hline \multicolumn{2}{c}{ One Sample Kolmogrov-Smirnov Test } \\
\hline \multicolumn{2}{c}{$\begin{array}{c}\text { Unstandardized } \\
\text { Residual }\end{array}$} \\
\hline $\mathrm{N}$ & & 51 \\
Normal & Mean & .000000 \\
Parameters ${ }^{\text {a.b }}$ & & 0 \\
& Std. Deviation & 2.90337 \\
& & 901 \\
Most Extreme & Absolute & .092 \\
Differences & Positive & 0.92 \\
& Negative & -.060 \\
Test Statistic & & .092 \\
Asymp. Sig. & & $.200^{\text {c.d }}$ \\
(2-tailed) & & \\
\hline
\end{tabular}

Diketahui nilai signifikansi (Asymp. Sig. 2-tailed) 0,200>0,05 nilai ini mengartikan bahwa data berdistribusi secara normal. Selanjutnya uji multikolinearitas, uji ini digunakan untuk menguji ada atau tidaknya hubungan depedensi linear antarvariabel independen.

\subsubsection{Uji multikolinearitas}

Dalam penelitian ini menggunakan Variance Inflation factor (VIF). Apabila VIF pada variabel bebas $<10$, artinya tidak terjadi multikolineritas dan demikian sebaliknya, apabila variabel $>10$ artinya terjadi multikolinearitas. Dan jika tolerance value diatas $>0,1$ maka tidak terjadi multikolinearitas. Hasil uji Multikolinearitas dapat dilihat pada tabel 3 berikut:

Tabel 3. Uji Multikolinearitas

\begin{tabular}{lccc}
\hline \multirow{2}{*}{ Variabel } & \multicolumn{2}{c}{$\begin{array}{c}\text { Collinearity } \\
\text { Statistics }\end{array}$} & \multirow{2}{*}{ Keterangan } \\
\cline { 2 - 3 } & Tolarance & VIF & \\
\hline $\begin{array}{l}\text { Kecerdasan } \\
\text { emosional }\end{array}$ & 0,228 & 4,384 & $\begin{array}{c}\text { Tidak terjadi } \\
\text { multikolineritas }\end{array}$
\end{tabular}

(X1) 


$\begin{array}{llll}\begin{array}{l}\text { Kecerdasan } \\ \text { sosial (X2) }\end{array} \quad 0,228 & 4,384 & \begin{array}{c}\text { Tidak terjadi } \\ \text { multikolineritas }\end{array}\end{array}$

Berdasarkan tabel 3 diketahui bahwa nilai VIF kecerdasan emosional (X1) dan variabel kecerdasan sosial (X2) adalah 4,384 $<10$ dan nilai tolerance value 0,228 $>0,1$ maka data tersebut tidak terjadi multikolinearitas. Dengan ini dapat disimpulkan bahwa uji asumsi klasik yang kedua telah terpenuhi.

\subsubsection{Uji Heteroskedasitas}

Uji asumsi klasik yang ketiga ialah uji Heteroskedasitas uji ini bertujuan untuk menguji apakah dalam suatu analisis berganda mempunyai ketidaksamaan varian dalam suatu pengamatan. Model regresi yang baik adalah model yang tidak terjadi heteroskedasitas. Metode yang digunakan dalam uji ini adalah metode Glejser. Uji ini memiliki ketentuan jika nilai signifikasi $>0,05$ maka tidak terjadi heteroskedasitas dan berlaku sebaliknya. Nilai signifikasi dapat dilihat pada tabel 4.

Tabel 4. Uji Heteroskedasitas Metode Glejser

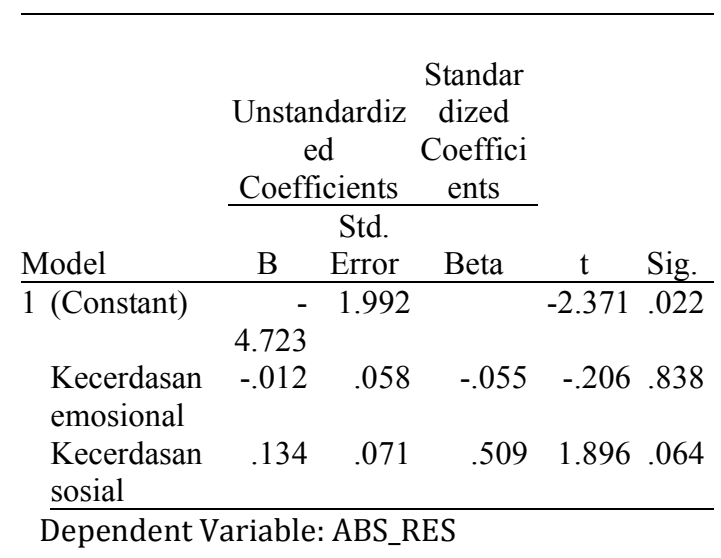

Diketahui nilai signifikasi (Sig.) untuk variabel Kecerdasan Emosional adalah 0,838. Sementara untuk nilai signifikasi (Sig.) untuk variabel Kecerdasan Sosial adalah 0,064. Karena nilai signifikasi kedua variabel penelitian ini > 0,05 maka keputusan dalam uji Glejser, dapat disimpulkan bahwa tidak terjadi gejala heteroskedasitas dalam model regresi. Sehingga model regresi layak digunakan.

\section{Hasil dan Pembahasan}

\subsection{Hasil}

Penelitian ini menggunakan pengujian hipotesis dengan menggunakan bantuan program SPSS versi 26. Pada tabel 5 nilai konstanta kecerdasan emosional (X1) dan kecerdasan sosial (X2) nilainya adalah nol, maka kinerja karyawan (Y) nilainya adalah $-2,045$. Koefisien regresi variabel kecerdasan emosional (X1) sebesar 0,295 artinya bahwa besarnya kinerja karyawan $(\mathrm{Y})$ akan mengalami kenaikan baik turun maupun naik, dengan kata lain apabila koefisien regresi kecerdasan emosional (X1) naik satu satuan, maka kinerja karyawan (Y) juga akan naik 0,295 satu satuan dan sebaliknya. Koefisien regresi variabel Kecerdasan Sosial (X2) 
sebesar 0,288 artinya bahwa besarnya Kinerja Karyawan (Y) akan mengalami perubahan sebesar 0,288 jika kecerdasan sosial berubah sebesar satu satuan baik turun maupun naik, dengan kata lain apabila koefisien regresi kecerdasan sosial (X2) naik satu satuan, maka kinerja karyawan (Y) naik satu satuan dan sebaliknya.

Dan juga dapat dilihat Berdasarkan tabel 5 nilai koefisien Determinasi $\left(\mathrm{R}^{2}\right)$ atau $\mathrm{R}$ Square sebesar 0,703 hal ini menunjukkan bahwa presentase sumbangan peranan variabel bebas (Kecerdasan Emosional dan Kecerdasan Sosial) terhadap variabel terikat Kinerja Karyawan (Y) sebesar 70,3\% (0,703 x 100\% = 70,3\%). Sedangkan sisanya sebesar 29,7\% dipengaruhi atau dijelaskan oleh variabel lain yang tidak dimasukkan dalam model penelitian ini.

Tabel 5. Uji Regresi liner Berganda

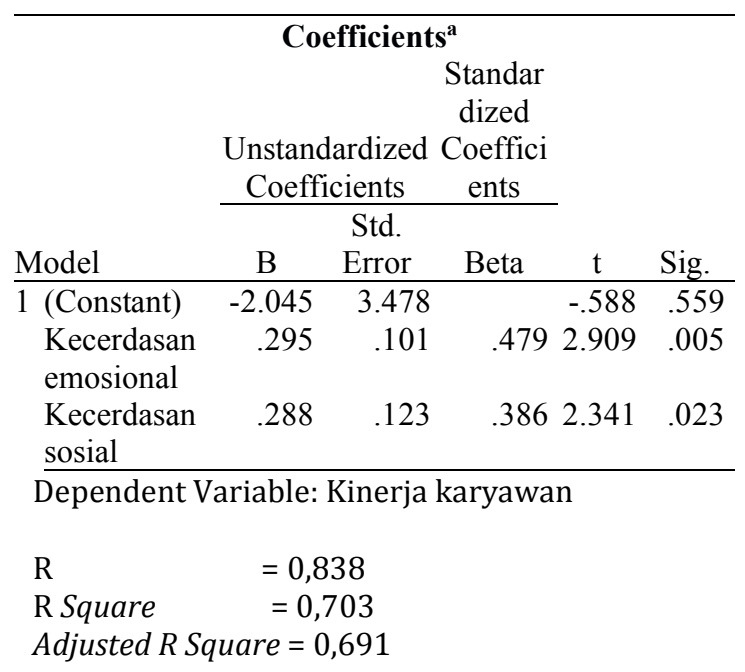

\subsubsection{Pengujian Hipotesis}

Tabel 6 menunjukkan bahwa hipotesis pada penelitian ini didukung. Hasil penelitian menunjukkan bahwa kecerdasan emosional (X1) berpengaruh positif dan signifikan terhadap kinerja karyawan $(\mathrm{Y})$ dengan melihat nilai t Hitung yang lebih besar dari nilai $t$ Tabel $(2,909>$ 2,010 ) dan nilai signifikasi sebesar 0,005 < 0,05 dapat disimpulkan bahwa H1 diterima H0 ditolak. Hal ini juga terjadi pada variabel kecerdasan sosial (X2) berpengaruh positif terhadap Kinerja Karyawan $(\mathrm{Y})$ dengan melihat nilai t Hitung yang lebih besar daripada nilai t Tabel $(2,341>2,010)$ dan nilai signifikasi sebesar 0,023 < 0,05 dapat disimpulkan bahwa H2 diterima dan H0 ditolak.

Tabel 6. Uji Hipotesis

\begin{tabular}{lcccc}
\hline Variabel & t Hitung & t Tabel & Sig. t & Taraf Sig \\
\hline $\begin{array}{l}\text { Kecerdasan } \\
\text { Emosional }\end{array}$ & 2,909 & 2,010 & 0,005 & 0,05 \\
$\begin{array}{l}\text { Kecerdasan } \\
\text { Sosial }\end{array}$ & 2,341 & 2,010 & 0.023 & 0,05 \\
\hline
\end{tabular}




\subsection{Pembahasan}

Berdasarkan hasil analisis di atas menemukan bahwa kecerdasan emosional berpengaruh positif dan signifikan terhadap kinerja karyawan bagian promotor produk pada PT. Blue Ocean Hearth kota Malang. hal ini berarti semakin tingginya kecerdasan emosional yang dimiliki karyawan akan membuat naiknya kinerja karyawan (Daniel Goleman, 2017) menyatakan bahwa seseorang yang dapat mengontrol emosinya dengan baik maka akan dapat menghasilkan kinerja yang baik pula, faktor yang sama pentingnya dengan kombinasi kemampuan teknis dan analisis untuk menghasilkan kinerja yang optimal. Penelitian (Pratama \& Suhaeni, 2017) kecerdasan emosional mengandung aspek-aspek yang dibutuhkan dalam bekerja seperti kemampuan memotivasi diri sendiri, mengendalikan emosi, mengenali emosi orang lain, mengatasi frustasi, mengatur suasana hati, dan aspek-aspek penting lainya. Jika aspek-aspek tersebut ada di dalam diri seorang karyawan maka akan membantu dalam mewujudkan kinerja yang baik. orang yang memiliki kecerdasan emosional yang tinggi adalah orang yang mampu mengatasi konflik dalam dirinya dengan baik. Dan penelitian (Amilia \& Purnama, 2016) mengungkapkan bahwa kecerdasan emosional berpengaruh positif terhadap kinerja pegawai dan mengungkapkan bahwa seseorang dengan kecerdasan emosional yang tinggi akan memperoleh hasil kinerja yang lebih baik dibandingkan dengan seseorang yang memiliki kecerdasan emosional rendah.

Penelitian ini juga menemukan bahwa kecerdasan sosial berpengaruh positif dan signifikan terhadap kinerja karyawan bagian promotor produk pada PT. Blue Ocean Hearth kota Malang. Hal ini berarti semakin tingginya kecerdasan sosial yang dimiliki karyawan akan membuat naiknya kinerja karyawan. Individu yang memiliki kecerdasan sosial yang kuat akan mudah berkomunikasi dan berinteraksi dengan proaktif tanpa mengganggu orang lain. Sementara individu yang memiliki kecerdasan sosial yang rendah akan bekerja sendiri, tidak mampu bekerja dalam tim secara menyatu dan solid. Individu tersebut sulit menyatu di dalam proses kerja. Hal ini sependapat dengan (D Goleman \& Boyatzis, 2008), mengatakan bahwa individu dalam melakukan pekerjaannya perlu memiliki kecerdasan sosial agar dapat menghasilkan kerja sama yang baik di lingkungan pekerjaan. Jika individu memiliki kecerdasan sosial, maka individu tersebut dapat lebih mendengarkan dan mempertimbangkan pandangan orang lain (Daniel Goleman, 2015). Hal ini juga memungkinan individu untuk dapat memberikan kontribusi yang efektif bagi suatu tim kerja di dalam organisasi. Jika seorang individu memiliki kecerdasan sosial yang rendah akan memberikan dampak negatif bagi organisasi karena akan berpotensi menjadi benih konflik dalam lingkungan kerja yang akhirnya mengakibatkan kinerja terbaik yang harus dicapai sulit diwujudkan. Penelitian (Lathesh \& Avadhani, 2018) mengungkapkan pengaruh kecerdasan sosial terhadap kinerja karyawan, karyawan yang mengadopsi keterampilan baru kecerdasan sosial dalam kehidupan kerja mereka membuat kinerja karyawan mereka sangat baik. (Koloor \& Seifollahi, 2018) hasil penelitian menunjukkan hasil bahwa 73 persen perubahan kinerja inovatif disebabkan kecerdasan sosial.

\section{Simpulan}

\subsection{Kesimpulan}

Berdasarkan hasil analisis statistik deskriptif dapat diketahui bahwa Kecerdasan emosional karyawan promotor produk di PT. Blue Ocean Hearth kota Malang dikategorikan 
tinggi atau cerdas secara emosional, tetapi fakta dilapangan masih belum semua promotor menerapkannya secara optimal kecerdasan emosional ketika bekerja. Seperti kurangnya pemahaman karyawan promotor produk terhadap perasaan-perasaan orang disekitarnya Seharusnya perusahaan lebih mengedukasi promotor bahwa kecerdasan emosional itu penting dalam pekerjaan yang mengutamakan interaksi agar pembeli memiliki keterikatan emosi dengan promotor dan pembeli tertarik dengan produk yang ditawarkan oleh promotor. Kecerdasan sosial karyawan promotor produk di PT. Blue Ocean Hearth kota Malang dikategorikan tinggi atau cerdas secara sosial tetapi faktanya kecerdasan sosial belum sepenuhnya dimiliki semua promotor. Ini dibuktikan promotor masih kesulitan dalam memprediksi keinginan dari pembeli itu sendiri. Jika kecerdasan ini dimiliki dan diterapkan dengan maksimal bisa saja menjadi faktor potensi kenaikan kinerja yang baik. Kinerja karyawan bagian promotor produk PT. Blue Ocean Hearth kota Malang dikategorikan baik. Hal ini menunjukkan bahwa PT. Blue Ocean Hearth kota Malang sudah berupaya untuk meningkatkan kinerja karyawan. Namun kondisi di lapangan seperti kurangnya kedisiplinan karyawan yang membuat potensi penurunan kinerja terjadi. Berdasarkan hasil penelitian terdapat pengaruh positif dan signifikan antara kecerdasan emosional terhadap kinerja karyawan, dan terdapat pengaruh positif dan signifikan antara kecerdasan sosial terhadap kinerja karyawan promotor produk PT. Blue Ocean Hearth kota Malang.

\subsection{Keterbatasan Penelitian}

Berdasarkan pada pengamatan dan pengalaman langsung peneliti dalam menjalani proses penelitian ini, ada beberapa keterbatasan penelitian yang dialami dan dapat menjadi faktor yang agar dapat diperhatikan bagi peneliti-peneliti selanjutnya dalam lebih menyempurnakan penelitiannya. Variabel kinerja dalam penelitian ini diisi oleh sesama rekan karyawan promotor dikarenakan atasan langsung promotor tidak mudah untuk ditemui. Dalam penelitian ini indikator kinerja bersumber dari jurnal dengan responden yang sejenis dengan penelitian ini, tidak dari dokumentasi perusahaan karena indikator kinerja ini bersifat rahasia. Adanya keterbatasan penelusuran dari jawaban responden dalam memilih pernyataan yang tepat, dikarenakan waktu yang singkat dan pengambilan data dilakukan saat jam kerja. Sehingga memungkinkan terdapat jawaban yang tidak sesuai dengan keadaan sesungguhnya

\subsection{Saran}

Saran yang dapat diberikan peneliti berdasarkan hasil penelitian adalah sebagai berikut. (1) Dengan melihat hasil penelitian yang telah dilakukan menjelaskan bahwa rata-rata setiap variabelnya sudah memberikan gambaran atau masuk dalam kategori baik, bagi perusahaan perlunya meningkatkan pengaplikasian kecerdasan emosional dan kecerdasan sosial yang dimiliki promotor. Berdasarkan nilai mean terendah pada variabel kecerdasan emosional pada indikator others emotion apprasial pada item pernyataan ke 7 mengenai pemahaman promotor tentang perasaan-perasaan orang disekitarnya yang menunjukkan nilai mean 3,00. Peneliti menyarankan kepada perusahaan agar memberi pemahaman kepada karyawan agar menerapkan kecerdasan emosional dengan baik agar karyawan mampu memahami perasaanperasaan orang dilingkungan kerja, yang tentunya akan berdampak pada kinerja karyawan.

Berdasarkan nilai mean terendah pada variabel kecerdasan sosial pada indikator social awareness pada item pernyataan ke 13 mengenai pemahaman karyawan mengenai hal-hal yang pembeli lakukan dan pada item ke 16 mengenai memprediksi pembeli. Saran bagi 
perusahaan memberikan pelatihan bagaimana cara melakukan interaksi yang baik kepada konsumen agar karyawan mampu memprediksi apa yang diinginkan pembeli dan memahami hal-hal yang pembeli lakukan. Sehingga membuat pembeli merasa nyaman. Pada variabel kinerja karyawan khususnya pada indikator kehadiran, saran untuk PT. Blue Ocean Heart kota Malang adalah lebih memperhatikan lagi tingkat kedisiplinan karyawan karena hal tersebut akan berdampak pada hasil kerja. 2) Penelitian ini digunakan sebagai referensi untuk penelitian dengan tema pengaruh kecerdasan emosional dan kecerdasan sosial terhadap kinerja karyawan. Dikarenakan penelitian dengan tema ini masih belum terlalu banyak diharapkan bagi peneliti selanjutnya bisa mengembangkan tema penelitian ini menjadi lebih luas dan diharapkan untuk menggunakan teori-teori yang berbeda sehingga penelitian dengan tema ini lebih luas dan bervariasi sehingga tema ini menarik untuk diteliti maupun dipelajari kedepannya.

\section{Daftar Rujukan}

Ambarita, F. A. (2014). Mengenal Kecerdasan Sosial. Badan Pendidikan dan Pelatihan Keuangan Kementrian Keuangan. Jakarta. Diakses dari http://www. bppk. kemenkeu. go. id.

Amilia, S., \& Purnama, R. (2016). Pengaruh Kecerdasan Emosional terhadap Kinerja Pegawai PT. Indonesia Comnets Plus Di Bandung. Jurnal Riset Bisnis Dan Investasi, 1(1), 24-30.

Arikunto, S. (2010). Metode penelitian. Jakarta: Rineka Cipta.

Collins, J. (2015). Good to Great. Jakarta: Gramedia Pustaka Utama.

Ghozali. (2012). Aplikasi Analisis Multivatiate dengan Program IBM SPSS 20. Semarang: UNDIP.

Goleman, D, \& Boyatzis, R. (2008). Social Intelligence and the Biology of Leadership. Harvard Business Review, 87(1), 108.

Goleman, Daniel. (2015). Social Intelligence: Ilmu baru Tentang Hubungan Antar manusia. Jakarta: Gramedia Pustaka Utama.

Goleman, Daniel. (2017). Kecerdasan Emosional : Mengapa EI lebih penting daripada IQ (Ketiga bel). Jakarta: Gramedia Pustaka Utama.

Jorfi, H., Jorfi, S., \& Moghadam, S. K. (2010). Impact of Emotional Intelligence on Performance of Employees at Manufacturing Organizations. International Journal of Recent Technology and Engineering, 8(3), 570572.

Koloor, H. R., \& Seifollahi, N. (2018). Investigating the effect of social intelligence on innovative performance (Case study: Moghan Agro-Industrial \& Livestock Co). Revista Publicando, 5(16), 2.

Lathesh, K. R., \& Avadhani, V. D. (2018). A study on social intelligence and its impact on employee performance of insurance sectors in mysuru city. International Journal of Mechanical Engineering and Technology, $9(1), 530-537$.

Law, K. S., \& Song, L. J. (2004). The Construct and Criterion Validity of Emotional Intelligence and Its Potential Utility for Management Studies. Journal of Applied Psychology, 89(3), 483-496.

Mamangkey, L. A. G., Tewal, B., \& Trang, I. (2018). Pengaruh Kecerdasan Intelektual (Iq), Kecerdasan Emosional (Eq), Dan Kecerdasan Sosial (Sq) Terhadap Kinerja Karyawan Kantor Wilayah Bank Bri Manado. Jurnal EMBA: Jurnal Riset Ekonomi, Manajemen, Bisnis Dan Akuntansi, 6(4), 3208-3217.

Mangkunegara, A. A. A. P. (2010). Manajemen Sumber Daya Manusia Perusahaan. Bandung: PT Remaja Rosdakarya.

Mathis, R. L., \& John, H. J. (2006). Manajemen Sumber Daya Manusia (Pertama). Jakarta: Salemba Empat.

Mudzakir, A., Muwaffiqillah, M., \& Muzakki, I. (2018). Hubungan antara kecerdasan sosisal dengan produktivitas kerja karyawan bagian penjualan. Journal of Psychology and Islamic, 2(1), 51-68.

Pratama, A. Y., \& Suhaeni, T. (2017). Pengaruh Kecerdasan Emosional terhadap Kinerja Karyawan. Jurnal Riset Bisnis Dan Investasi, 3(2), 51-62.

Rahmasari, L. (2012). Pengaruh Kecerdasan Intelektual, Kecerdasan Emosi dan Kecerdasan Spiritual Terhadap Kinerja Karyawan. Majalah Ilmiah INFORMATIKA, 3(1), 1-20. 
Jurnal Ekonomi, Bisnis dan Pendidikan, 1(5), 2021, 439-451

Silvera, D. H., Martinussen, M., \& Dahl, T. I. (2001). The Tromso Social Intelligence Scale, A Self-Report Measure of Social Intelligence. Scandinavian journal of psychology, 42(4), 313-319.

Sugiyono. (2016). Metode Penelitian Kuantitatif, Kualitatif, dan R\&D. Bandung: Alfabeta.

Sumiyarsih, W., Mujiasih, E., \& Ariati, J. (2012). Hubungan Antara Kecerdasan Emosional Dengan Organizational Citizenship Behavior (OCB) Pada Karyawan CV. Aneka Ilmu Semarang. Jurnal Psikologi Universitas Diponegoro, 11(1), 19-27.

Utami, C. W. (2006). Manajemen Ritel: Strategi dan Implementasi Modern. Edisi Pertama. Jakarta: Salemba Empat.

Utomo, F. H., \& Suharyono. (2017). Pengaruh Kecerdasan Emosional Terhadap Adaptive Selling dan Dampaknya Pada Kinerja Tenaga Penjualan. Jurnal Administrasi Bisnis, 49(2), 49-55. 